\title{
The Resolution of Boundary Disputes between the Habsburgs and the Venetians in Istria by the Arbitral Decision of 1535
}

The Habsburgs' estates and the Venetian communes had a long boundary in northern Italy and Istria. Because of the specific circumstances in which the inter-state boundary was formed, it was constantly plagued by uncertainties and misunderstandings, which often resulted in local hostilities and violence. The escalation of boundary problems occurred at the beginning of the $16^{\text {th }}$ century, simultaneously with the formation of the League of Cambrai and the war between its allies and Venice. The war incited the two political powers (and disputants) to search for a means of resolving the boundary disputes peacefully. For this, arbitration was arranged between them in Trento (Trident) in 1535, of which several archival sources have been preserved. The paper analyses the Trento Agreement of 1535 according to the manuscripts in the state archives in Venice and Vienna as well as some other fragmentary texts on local arbitration following the model of Trento. The author specifically examines arbitrations in which the boundary disputes were resolved in Istria.

Keywords: Arbitration - boundary - the Habsburgs - Istria - League of Cambrai - Venice

\section{Introduction}

At the beginning of the $16^{\text {th }}$ century, the estates governed by the Habsburgs and the communes subjected to Venice came into direct territorial contact along the boundary which stretched from northern Italy to Istria. The boundary sometimes manifested as a line, in other places it was a strip of land or an area, while often it did not correspond to any jurisdictional delimitation.

This boundary was not drawn instantly. Initially, before the two powers came into territorial contact, these were separate local boundaries that had nothing to do with one another, and at that stage they were surely not intended to serve as the inter-state delimitation. They had their own traditional regimes, quarrels and disputes that were manifested in narrow local relations. Once their nature changed and they became inter-state frontiers, they were transformed into places of confrontation between the locals living on the opposite sides.

The idea of a boundary in the West was not the same at all times or in different circumstances. It had a permanently changing nature, ${ }^{1}$ depending on the means and modes in which different rulers claimed the territory and placed territorial limits on what they claimed. In Roman times, it was manifested in private relations as a strip of land five feet wide, ${ }^{2}$ while in interstate relations it might have been in the shape of a line or, in some specific areas (e.g. the African limes) it was fluid and conceived as a territory that functioned like a membrane within the seasonal migrations of people. In the West, the concept of the boundary in the ius commune was strongly

\footnotetext{
${ }^{1}$ KHAN, Territory 240-241.

2 Scattola, Die Grenze 43.
} 
conditioned by the wording of the Corpus iuris civilis. ${ }^{3}$ The boundary served as the end of territorium, terrae spatium, but also as a jurisdictione munitum, which could refer to the separation of territories, but also to the separation of jurisdictions which did not necessarily coincide with territorial delimitations. ${ }^{4}$ However, it is impossible to describe the actual boundary with reference to general perceptions of ius commune because its nature and shape were deeply conditioned by the very local circumstances in which it could take a wide variety of forms. For example, as a reaction to the plague epidemics in the $17^{\text {th }}$ century (especially in the thirties), in certain areas, the boundary between the Habsburgs and the Venetians in Istria was in the shape of a strip of land two kilometres wide, which served as a cordone di sanità along the main road (Strada detta dell'impero), which connected to the territories. ${ }^{5}$ It was simultaneously a wide sanitary and military boundary belt that served as a quarantine area fortified with sanitary and military stations.

This paper provides an insight into how the Habsburgs and Venetians attempted to resolve the boundary problem in 1535 by way of an arbitration arranged in Trento [Trient]. It examines several manuscripts in which the arbitration of 1535 is recorded, but it is primarily concerned with the boundary dispute resolution in Istria achieved in the arbitral awards of 1535 that were successively rendered in Pazin [Mitterburg] and Trieste. The paper demonstrates the results of the author's research of the boundary problem in Istria, and provides perspectives for further

\footnotetext{
${ }^{3}$ MONTI, Tractatus 2

${ }^{4}$ Ibid. 17-19.

${ }^{5}$ Linea del Conf[ine] tra l'Istria Veneta, et Austriaca descritta [...] of 1713. A map with accurate descriptions of the relevant boundary is preserved in the State Archive in Venice and was published in RossiT, LAGO, Descriptio 211.
}

research and analysis of the Viennese manuscript (a copy from the Austrian State Archives).

\section{Relevant historical background}

The boundary between the Habsburgs' estates and the Venetian communes in northern Italy and Istria in the late Middle Ages has been qualified as a constantly disputed matter. ${ }^{6}$ The problem involved not only the rulers from both sides, but also a large number of people living on the boundary or in its surroundings. The boundary between the Habsburgs and Venetians became an even larger issue after 1420, when the Patriarchate of Aquileia lost its civil authority over large portions of northern Italy and Istria. In most cases, the Venetians took possession of the properties of the Patriarchate and thereby came into direct territorial contact with the estates under the Habsburgs' rule. ${ }^{7}$

The formation of a boundary between the Habsburgs and the Venetians did not happen instantly. It was a result of a long-lasting political process in which, by diverse means and at different periods, the two supreme powers gradually seized the neighbouring communes and estates. In such circumstances, the pre-existing local boundary between two (or more) relatively small and insignificant territories became a strategic demarcation line between two universal powers. For this, at least in the late Middle Ages and up until the $16^{\text {th }}$ century, the boundary line between the Habsburgs' and Venetian spheres of interest was not permanent; it was subjected to constant changes and redefinitions, resulting in extreme tensions and uncertainties. The shape of the boundary was never final because its formation was based on gaining or losing the su-

\footnotetext{
${ }^{6}$ JURIČIĆ ČARGO, Spopadi 45; LAW, The Venetian 153-154. ${ }^{7}$ CUSIN, Il confine 181-227; PASCHINI, Storia 727ff.
} 
preme authority over a particular political unit, rather than on territorial conquest. ${ }^{8}$

Boundaries, whose formation occurred in this specific way, gave rise to multiple disputes. They inherited the pre-existing traditional quarrels and misunderstandings that represented a constant in the inter-communal relations of the Middle Ages. Even before the territorial (boundary) contacts of the Habsburgs and Venetians, medieval documents often refer to "differenti$\mathrm{ae}^{\prime \prime}$. The term signifies not necessarily a boundary line, but an area near the boundary that was in a specific way attached to boundary disputes. "Differentiae" were areas which were not subject to a regular property regime because the inhabitants from both sides of the boundary traditionally used them, i.e. they were reserved for common use. In most cases, these areas encompassed vital natural goods such as water sources, woodlands, pastures, arable land etc. Their common use necessarily led to misunderstandings and to each side's desire to capture them for their own use, which resulted in their description as a disputed territory ("territorio contentioso"). ${ }^{9}$

Because the boundary line between the Habsburgs and Venetians was not instantly fixed, it was often connected with uncertainties with regard to its precise position. The problem was even further aggravated by the fact that the territorial boundary in the Middle Ages did not necessarily correspond to the boundaries of the fiscal jurisdiction. ${ }^{10}$ This was well-attested in the

\footnotetext{
${ }^{8}$ MiLotić, Aspetti 111-145.

${ }^{9}$ IDEM, La Sentenza 350ff.

${ }^{10}$ Fiscal jurisdictions were not and even today often still do not correspond to the territorial boundaries of the administrative entities under canon law. E.g. the diocese does not necessarily have full or any fiscal jurisdiction over the monasteries on its territory and vice versa. Moreover, in the Middle and Modern Ages the church entities or higher church officials might assume civil powers (plenum ius) and dominion over territories (communes, estates etc.) and fully exercise
}

famous case of the village of Zamask [Zamas$\mathrm{co} /$ Zumesco] in Istria, where even after the boundary settlement of 1535, the Habsburgs' vassals owed certain tributes to the neighbouring Venetian commune of Motovun. ${ }^{11}$ The case depicts a situation in which the fiscal jurisdiction stretched beyond the territorial limits. Initially, such challenges represented a local problem. However, once the local boundary between the two communes evolved into an inter-state delimitation, the "local irritations" evolved into potential triggers for potentially much largerscale hostilities.

Istria in the late Middle Ages and the early Modern Age represents all the dangers that might emerge from an unclear boundary line. Its geographically compact territory was politically divided on the estates that recognized the supremacy of the Habsburgs, which covered $1 / 3$ of the territory, while the communes, whose territories covered $2 / 3$ of Istria, were subjected to Venice.

The devastating effects of such boundary situations, not only in Istria but also on the vast territories of northern Italy, became apparent after the formation of the League of Cambrai in 1508. The League's intention was to attack the Republic of Venice and divide its territories among the allies. The major battlegrounds were located in northern Italy and Istria because the allies predominately struggled for control over Venice's

them as if they were lay rulers, which additionally resulted in a lack of correspondence between territorial and fiscal jurisdictions. Outside canon law (as well as of church entities and officials), differences between territorial and fiscal jurisdictions were, in most cases, a result of a complex set of circumstances in the particular locality. On many occasions, these were conditioned by traditional (ancient) legal regimes or territorial holdings which were later changed or adapted, but the reflections of the previous jurisdictions remained. It seems that the former occurred in the case of the village of Zamask. See e.g. STEIGER, Von der Staatengesellschaft 357-381.

${ }^{11}$ JOKSIMOVIĆ, ŠIPOŠ, La Sentenza 300-301. 
mainland (Terraferma), for which the intercommune boundary line was of the utmost importance. The war eventually ended with the triumph of Venice (for it retained or regained the lost territories) despite its many military defeats. ${ }^{12}$ The impacts of the war in Istria were felt on the boundary line or in places that were close to or attached to it. All modifications of the post-war boundary went in favour of Venice, which for the first time captured some small forts and villages of considerable strategic significance. Such small territorial advances provided Venice with an important psychological advantage in the forthcoming post-war events, which were all concentrated around the disputed boundary.

The War of the League of Cambrai put forth a problem of the undetermined boundary line between the Habsburgs' estates in the Istrian mainland and the Venetian communes located in the coastal regions. The War was a starting point of an overall escalation of violence along the boundary line, which both sides instantly detected as a point in their relations that they could not overcome. For this reason, in 1535 they attempted to resolve their boundary disputes by way of arbitration, which is the topic of this paper.

The real background of the conflict in Istria and in the areas of northern Italy which gravitated toward the Adriatic was always the strategic port of Trieste, its surroundings and the nearby salt pans which were controlled by the Habsburgs, although they were surrounded by the Venetian territories. The conflict was never constrained solely to these issues, but always had an impact on the whole boundary line, bringing permanent turmoil to the territories and populations living along it.

\footnotetext{
${ }^{12}$ Finlay, Fabius 990-992; MeregaZZI, Pauli 456-457.
}

\section{Archival sources of the arbitration of 1535}

The sources of the 1535 arbitration have survived in several manuscripts. Because the 1535 arbitration file is a collection of the principal arbitration of Trento and a large number of "local arbitrations" (which were arranged on its grounds for a specific section of the boundary), records of that dispute resolution exist in different forms. A number of shorter manuscripts depict arbitration procedures over certain smaller sections of the boundary or over a separate location or a strip of land that was highly disputed. These are extracts from the original Trento arbitration file which were purposefully copied. The manuscripts underwent language adaptations, thereby departing from the original wording in Latin. They are written in Italian or in the Istrian-Venetian dialect, or some other local idiom. ${ }^{13}$

The second form in which the 1535 arbitration appears is a manuscript in Latin, a copy of the original, containing summarized records (a sort of a catalogue) of many particular ("local") dispute resolutions in northern Italy and Istria. The manuscript is preserved in the Austrian State Archives ${ }^{14}$ and deserves an in-depth examination in the future.

The third form in which the 1535 arbitration appears are collections of scripts containing local arbitrations for broader sections of the boundary line in a certain region or a separate territory. In 2017 a study of the Trento arbitration was published on the ground of an arbitration file which survived in the State Archive in Venice. ${ }^{15}$ The

${ }^{13}$ Budicin, Contributo 223-268; KANDLER, Notizie 207-210; LUCIANI, Capo d'Istria 1891a, 155-202; IDEM, Capo d'Istria 1891b, 355-409; IDEM, Capo d'Istria 1892, 409-478.

${ }^{14}$ Austrian State Archives in Vienna [Wien], OeStA, HHStA, UR AUR 1535 VI 17.

${ }^{15}$ State Archive in Venice [Venezia], Deliberazioni Senato Rettori, busta Nr. 181 (further: ASV, D, b. 181). 
file reveals arbitration on the most disputed sections of the boundary line in Istria. ${ }^{16}$

The Latin key wording of the archival source suggests that the arbitration was not about the land as such. It exclusively refers to "territorium", meaning the land under jurisdiction of one or other party to the dispute, i.e. an area under its full control. ${ }^{17}$ The language of the arbitration, specifically the key words, reflects the terms which appeared in such legal contexts in late medieval Europe. This is additionally affirmed by the use of the word "dominium", signifying exclusive control over "territorium", which has the central place in it. It characterizes each disputant in the arbitration of 1535 as Il Stato, which fully corresponds to juridico-political trends and processes which were going on in Europe from the late Middle Ages onwards. ${ }^{18}$

\section{Why arbitration?}

In general terms, the Habsburgs and Venice were two different and completely incompatible rulers. They were independent from one another, separate and autonomous. They recognized no higher authority on their territories. For that reason, disputes among them could not be contested in any common court. Next, we come to the enforceability of a decision that a third person, entity or court would make in dispute between them. Because these were separate and independent powers, there would be no means to enforce such decision. Moreover, their legal traditions were incompatible: Venice explicitly rejected the ius commune and insisted that all its laws were self-designed within the discretion (arbitrium) and initiative of magistrates in the

\footnotetext{
${ }^{16}$ BRADARA, Il Confine.

${ }^{17}$ KHAN, Territory $231-232$.

18 SASSEN, Territory $123 \mathrm{ff}$.
}

making and interpretation of the law, ${ }^{19}$ while the Habsburgs' estates relied more on ius commune. In such circumstances, any effective boundary settlement necessarily required an agreement of both sides (acting on equal footing), and thereby their voluntary subjection to an ad hoc court which they would establish for that particular matter. This meant that they could only employ inter-state arbitration. Arbitration was attractive for another reason: it enabled each party on equal footing to select one arbitrator, while the third (impartial) arbitrator was selected by both of them. The Tenor sententiae Tridentinae (which is the official name of the Trento arbitration) follows such pattern of appointing arbitrators, which evidently comes from Roman law. An option to have two arbitrators, each appointed by one disputant, was unsustainable in case of dissenting opinions, for which a third impartial arbitrator was required. ${ }^{20}$

The wording of the archival source at hand links the Trident arbitration to mediation by mentioning that the third impartial arbitrator is at the same time a mediator (not an amicabilis compositor). The source does not provide any reasoning or explanation of the precise meaning of bringing together the two means of dispute resolution. We believe that mediation might have been employed because the arbitration (arbitrium) in the Middle and Modern Ages was consistently modelled on the grounds of the classical Roman arbitration ex compromisso (which is substantially different to the classical arbitrium boni viri and medieval amicabilis compositio), which allowed the arbitrator to do nothing else in his award other than to ultimately proclaim who was right and who was wrong. Arbitration

\footnotetext{
19 Povolo, Liturgies 534.

${ }^{20}$ Selecting multiple arbitri was associated with risks in case of dissenting opinions. It could be prevented by selecting an odd number of arbitri: each party selected his own arbiter, and afterwards they would reach a consensus on the third arbiter. D 4, 8, 17, 6 .
} 
at the time which is relevant for this paper, especially the one that addressed inter-state relations, did not allow the arbitrator to resort in his decision to negotiated justice or negotiated settlements, which, at the other hand, the boundary disputes often necessitated. We believe the indication of mediation should be interpreted as a means of compensation for the rigidity that deciding the case by arbitration may bring and which could potentially lead to an outbreak of hostilities between the disputants. However, only the third impartial arbitrator was vested with mediation powers, which most distinctively differentiated him from the two arbitrators, who were selected by the disputants.

\section{Arbitration agreement}

Different manuscripts focus on different aspects of the boundary line, ranging from a holistic approach to narrow considerations constrained to a certain place or area. Nevertheless, the initial part of all manuscripts reveals the process in which arbitration was arranged. They mention an act indicated as "litterae patentes" - signifying an arbitration agreement between "Serenissimi Romanorum Regis" and "Illustrissimi Dominii Veneti". The agreement is also indicated as compromissum, which additionally clarifies that the model of arbitration came from Roman law. ${ }^{21}$ In the Romano-canonical procedure of the Middle Ages, compromissum signifies the legal foundation of an arbitrator's obligation to settle the dispute finally and with binding force, ${ }^{22}$ while the parties should abide by it and proceed to implement it. ${ }^{23}$

\footnotetext{
${ }^{21}$ E.g. D 4, 8, 1.; COING, Zur Entwicklung 35-46; ZIMMERMANN, Law of Obligations 528-530.

22 ZIEGLER, Arbiter 376-381; ZIMMERMANN, Law of Obligations 528-530.

${ }^{23}$ FOWLER, Forms 144; FOWLER-MAGERL, Ordo iudiciorum 247-250.
}

"Litterae patentes" (or "compromissum") laid down the arbitration pattern and standard for all the local (forthcoming) arbitrations. The Trento arrangement was not intended to be directly operative. It only set out the model and provided an initiative for the local arbitrations to become operative. The Viennese manuscript records a large number of local arbitrations in northern Italy and Istria which were initiated on the grounds of the Trento Agreement to determine the boundary only between a single Habsburg estate and a Venetian commune.

The initial part of "litterae patentes" / "compromissum" records the selection of arbitrators ("nominatio et electio arbitratorum"), which corresponds with the standard contents of the ad hoc arbitration arrangements. ${ }^{24}$ Both sides chose persons with a relevant legal background ("iurisconsulti"): the Habsburgs appointed the royal judge Antonius Queta while the Venetians selected Mathias Avogadro. ${ }^{25}$ The persons appointed by the parties were not impartial or objective arbitrators. They were both high-level legal officials and office holders in the administration of the disputant who selected them, which is explicitly indicated. For this, a third person was required, who would then represent the disinterested factor of the arbitration at hand, its impartial and objective component. These two then reached an agreement over the third (impartial) person - Ludovicus Porro, a "superabiter", who together with the first two constituted the ad hoc arbitration court of three men (odd number). Ludovicus Porro is additionally referred to as "mediator communis", suggesting that he was not only an adjudicator. He may have acted as a mediator or a peacemaker between the two confronted parties. Ludovicus Porro apparently had two different

\footnotetext{
${ }^{24}$ Milotić, La Sentenza 344; JOKSIMOVIĆ, ŠIPOŠ, La Sentenza 296.

${ }^{25}$ ASV, D, b. 181, 1; JOKSIMOVIĆ, ŠIPOŠ, La Sentenza 296.
} 
roles because, in the civil procedure of the time, the arbitrator is a substantially contrasted mediator. ${ }^{26}$ Any mention of a mediator in this arbitration must be interpreted in the legal context of the Early Modern Ages. His employment in the inter-state arbitration of that time had to prevent warfare among the disputing parties and sustain peace. ${ }^{27}$ However, his employment blurs the distinction (even the nomenclature) between arbitration and mediation in the dispute at hand. This may be justified if, already at this point, a reference is made to the wording of the award of the Trident arbitration. One may distinguish different approaches to the settling of disputes for different sections of the boundary: somewhere the boundary was settled in a clear-cut resolution (e.g. the village of Zamask), elsewhere it was apparently negotiated with no unilateral preferences or firm regimes ("loca differentiarum"), while in other places the settlement was not reached at all. The same pattern of appointing arbitrators was mirrored in the local arbitrations that followed the Trento Agreement. For instance, in the arbitration of 8 October 1535 conducted in Pazin, a royal captain in Duino - Johannes Hoffer - was appointed superarbiter by the two arbitrators, each selected by one disputant (the Venetian commune of Montona and the Habsburgs' representative Captain Luigi Moscon of Pazin). ${ }^{28}$

\section{Arbitration in Istria}

\subsection{General remarks}

The arbitration of Trento (Trident) of 17 June 1535 was fundamental and served as a model for subsequent local ones. As a model, it

\footnotetext{
${ }^{26}$ DURANTIS, Speculum $\S 1,3$.

${ }^{27}$ KAMPMANN, Arbiter 14-15, 30-31; ZIEGLER, The influence 151-152.

${ }^{28}$ ASV, D, b. 181, 6; Joksimović, ŠIPOŠ, La Sentenza 311.
}

defined the structure, means of appointing arbitrators, their number and the procedural standards of arbitrations (especially with reference to evidence).

The Viennese manuscript covers all of the disputed areas, in relation to which it provides only a brief overview of the parties, basic facts and determinants of each case. Much differently, the Venetian manuscript gives an insight into a narrow disputed territory (of Istria), in relation to which it provides profound descriptions of the boundary section. Of such a manuscript we can make more use in order to identify how arbitration came to function in practice.

\subsection{Disputed matters}

The Trento arbitration addressed Istria with several provisions:

(1) The restoration of the possessions, income, expenses and damages as they were prior to the War of the League of Cambrai ("prout ante bellum" or "quemadmodum ante bellum"). ${ }^{29}$ The War of the League of Cambrai via facti remodelled the traditional division of the Habsburgs' and Venetians' communes in Istria. The intention of the Trident arbitration was to restore the territorial division and political supremacy which existed before the War. There is only a single case of the restoration of territory that the arbitration achieved and of which we are aware. The fort of Momiano, which had been captured by the inhabitants of Koper (who recognised the Venetian rule) in 1508, was - by means of the award - legally restored to the Raunichers, a German family, and simultaneously to the Habsburgs' supremacy. The Raunichers never returned to the fort; in 1521 they sold it to the Venetian family Rotta, whereby the fort changed the political supremacy as well. ${ }^{30}$

\footnotetext{
${ }^{29}$ ASV, D, b. 181, 1 and 4(2a).

30 "Haeredes domini Bernardini Raunicher restituendos esse ad castrum Momiliani cum jurisdictionibus
} 
(2) The fiscal regimes in the disputed boundary areas which were corrupted during and after the War. The Venetian commune of Montona traditionally had a certain fiscal jurisdiction over the income of the persons subjected to the Habsburgs' rule. ${ }^{31}$ There were three types of such income ("terraticum", "herbaticum", "podestaria") to which the Venetian commune of Montona was entitled. In 1533 and 1534, which preceded the arbitration of Trident, the imperial vassals with no sustainable reason refused to perform their fiscal duties to the neighbouring Venetian commune, which gave rise to the typical property disputes not over the existence of these right and duties, but rather over the imperial vassals' failure to perform them. The fiscal rights originated in an earlier age - when the commune of Montona encompassed the territories which were later separated from it and attached to territorial units under the Habsburgs' rule. The initial fiscal regime, which is well recorded in the medieval statute of Montona, remained after these territories' separation from Montona and was considered to be the traditional income of the Venetian commune of Montona in the Modern Period. ${ }^{32}$

(3) The boundary definition in the village of Zamask, which was highly disputed and ultimately divided into two parts (Venetian $\mathrm{Zu}$ mesco and Austrian Zamasco). The award settled the direction in which the division was performed. ${ }^{33}$ The dispute over this strategic hilltop village had been over 200 years old, which means that it went back to the period when the Habsburgs' rule was established in Istria for the first time. Many unsuccessful attempts were

infrascriptis et aliis redditis et pertinentiis suis". TOMMASINI, De Commentari 286; Milotić, Capitolare 66-74.

${ }^{31}$ ASV, D, b. 181, 4(2a) and 8(4a).

${ }^{32}$ Chapters Nr. 87, 185, 240, 247 and 262 of the Statute of Montona (Archeografo triestino, year 1894, 447-482 and year 1895, 5-120).

${ }^{33}$ ASV, D, b. 181, 1 (2) made in the course of this period to determine its belonging, i.e. who possessed it - the Venetians or the Habsburgs - but they never produced an adequate result. The arbitration of Trident divided the village in two parts, which has survived ever since in communal divisions and in the cadastre of the 1820s. ${ }^{34}$

(4) The preservation of the legal interest of the captain of Pazin, who was an official the Habsburgs. ${ }^{35}$ The provisions addressing the captain were formulated in a way that the boundary definition should not restrict or endanger his legal rights. Its formulation was justified on the grounds of peace achievement and its preservation ("pro bono pacis"). Such a provision immobilized the dispute resolution and award rendering to a substantial extent because all determinations should ultimately conform to the captain's interests.

(5) The prohibitory instruction to the parties to stay bound by the award and not to do anything to the contrary. ${ }^{36}$

The first local arbitration emerging from the Trento arbitration was conducted in Pazin on 8 October 1535. It consistently followed the model and tasks set out by the Trento arbitration. The three arbitrators undertook an inspection to gain a direct insight into the locations of the dispute. The arbitration dealt with "loca differentiarum" and "territorio contentioso" ${ }^{37}$

The second arbitration was conducted in Trieste on 18 October 1535 . It principally dealt with the setting of the boundary markings according to the Trento and Pazin awards. ${ }^{38}$

\footnotetext{
${ }^{34}$ ASV, D, b. 181, 3 (2).

${ }^{35}$ ASV, D, b. 181, 6(3a).

${ }^{36}$ ASV, D, b. 181, 4(2a).

${ }^{37}$ ASV, D, b. 181, 9(5), 10(5a).

${ }^{38}$ ASV, D, b. 181, 10(5a), 11(6).
} 


\subsection{Arbitration procedures}

The Trento arbitration file places disputants in an equal position which was consistently followed at the local levels. Arbitration on equal footing meant equality in the selection of arbitrators and subsequent equality of arms in the procedure. Such values are explicitly attested in the descriptions of the procedural request put before the arbitrators: "[...] responsione partis adverse, exceptionibus et oppositionibus utrinque factis, attestationibus, instrumentis, allegationibus, caeterisque iuribus, ab utraque parte productis, de quibus in actis ac aliis videndis [...]"39 The procedure had to ensure equality when the claim and counterclaims were put forward. It demanded an adversarial and contradictory procedure with provisions, enabling each party to be instantly heard, i.e. to provide it with the possibility to directly respond to what the other disputant alleged and to simultaneously produce evidence for its counterclaim. The procedure was governed by immediacy, being applied not solely to discussions, but also to terrain-based inspections. The arbitration of Trento insisted that the arbitrators visit and see the disputed boundary line with their own eyes. The procedural equality was facilitated in producing evidence: "[...] pars contendat se possedisse et testes super ea re contrarios, iuraque invicem repugnantia produxerint" ${ }^{40}$ There were several main forms of evidence employed: on-site inspection, documents and witnesses. The arbitrators demanded that witnesses were "idoneis, notis, probis, uocatis, rogatis, et adhibitis". ${ }^{41}$ Both sides were equally entitled to propose and produce evidence. Each arbitration court had powers to make judgments on witnesses' credibility. Witnesses (testes) were often explicitly mentioned in the awards while, on the

\footnotetext{
${ }^{39}$ ASV, D, b. 181, 1(2).

${ }^{40}$ ASV, D, b. 181, 2 (3)

${ }^{41}$ ASV, D, b. 181, 5 (3).
}

other hand, there are no references to documents, inspections or any other type of evidence. It leads us to the conclusion that witnesses' statements were the most important, and that decisions were primarily witness-based.

\subsection{Decision-making and enforcement}

The principal task put before the arbitrator was to determine the disputed boundaries. This means that, after they had evaluated all pieces of evidence, the arbitrators were bound to define the boundary on site (confinatio). Next, they were bound to draw a boundary line on the terrain as a result of the inspection that they had previously undertaken. Finally, the two local arbitration awards (of Pazin and Trieste) recorded the placement of the boundary markings (terminus, confinium) on the exact place where the boundary line was determined. The three-year research we conducted, in which the boundary line in Istria was examined in all its aspects (maps, documents, material remains etc.) revealed that boundary definitions actually took place and that, at least in some parts or in certain locations, they were enforced and made visible by placing boundary markings (stones, crosses, piles of stones etc.). There is a reliable and accurate record of an award in which the village of Zamask was divided in two halves. Nowadays in the land registers and cadastre the small village is still administratively divided in two parts. However, we may with great certainty conclude that not all the sections of the boundary line were determined, or at least that they were not determined precisely. In the upcoming years, decades and centuries, this gave rise to an escalation of violence and severe hostilities.

There are several important reasons which prevented the award from being fully executed. It had no real binding force, which gave enough leeway for each party to depart from it wherever or at whatever occasion it was not satisfied with the wording of the award. There was no guarantor or third supreme authority who could con- 
trol its enforcement or exert pressure on the parties to conform to what the arbitrators had decided. In some sections or specific localities along the boundary, no means of dispute resolution were adequate to reach a solution because the disputes were profound, long-lasting (traditional) and, additionally, in different sections the boundary might have manifested differently or appeared in different forms (such as a line, strip of land, corridor, vast undefined area, common goods such as the forest, pastures etc. which were traditionally used by the entire population that lived along the boundary etc.). Finally, there was never an adequate degree of willingness to resolve all the difficult issues along it. It seems, hypothetically, that the only means to resolve such a dispute would be a complex inter-state treaty that would require a lot of patience, negotiation, compromises and concessions, for which none of the disputants was ever ready.

The restoration of possessions and income (which was illegally collected by the Austrians in 1533 and 1534) was proclaimed in favour of the Venetian commune of Motovun, however, its full enforcement was not successful.

The regime over "loca differentiarum" and "territorium contentiosum", which was a true "cancer" of the boundary and a cause of the war in Istria, was not addressed by the awards. "Loca differentiarum" and "territorium contentiosum" remained a permanent "cancer" in local interstate relations until 1797.

The two most complete manuscripts of the arbitration of 1535 (the Venetian and the Viennese) contain no record of its ratification. An overview of the other relevant archival sources (that reveal only partial records of the arbitration at hand) says nothing about the Tenor Sententiae Tridentinae once the decision was made. In this regard, there are strong grounds to claim that the Sententia Tridentina was not ratified. The arbitration arrangement of 1535 and the following arbitration procedure were surely not formally qualified or perceived as a peace treaty, although its real function was to make peace and to keep it along the boundary line. On several occasions, the wording of the arbitration indicates that peace-making was the principal motive and an ultimate goal of the procedure. Nevertheless, the wording of that arbitration is missing all the specific clauses which at the time were the standard and the most recognizable contents of peace treaties. ${ }^{42}$

The Trident arbitration of 1535 was a dispute resolution on contractual grounds, representing the specificity of arbitration. The archival file at hand is primarily a decision with only a brief reference to how the agreement (contract) was made. The arbitration award necessitated no approval or ratification once it was rendered because all the arrangements and approvals were made in the arbitration arrangement phase, most probably by signing and sealing the arbitration agreement and selecting arbitrators which, at least in theory (having in mind these two specific disputants), invoked its binding force. ${ }^{43}$ At that point, the disputants took all the risks, including the risk that one of them might not conform to whatever the arbitrators would render. Otherwise, i.e. in case of its disappointment, each party could depart from the execution of the award by refusing to ratify it, arbitration would not be a sustainable means of resolving inter-state disputes. We believe that these are the main reasons why there is no evidence that the award was ratified.

\section{Conclusions}

The arbitration of 1535 between the Habsburgs and the Venetians was an attempt to settle the inter-state boundary dispute peacefully using rational legal means. In that particular interstate dispute resolution, arbitration was exploit-

\footnotetext{
${ }^{42}$ LeSSAFER, Peace Treaties $79 \mathrm{ff}$.

${ }^{43}$ Ibid. 75-76.
} 
ed in combination with mediation, which represents its unconventional use - in inter-state relations, i.e. outside the traditional arbitral ambient of private law.

Manuscripts which contain the text of the arbitration indicate a standardization and consistency in all the proceedings. Local arbitrations were fully governed by the principal arbitration of Trento. They are the local mirrors and derivations of the general settlements arranged in Trento. The manuscripts differ among themselves in the approach, i.e. whether they record the dispute resolution holistically (for the whole boundary like the Vienna manuscript) or for a particular section, area or even a specific position along the boundary. Each of the arbitrations most probably had its own file, i.e. a collection of texts that were of relevance for a particular dispute resolution in a certain place. Summarized versions of such particular arbitrations were collected and inserted into the principal Trento file, of which we have substantial data.

In Istria, we read of at least three local arbitrations (of two we have substantial knowledge from the State archive in Venice, while one is only indicated in the Viennese manuscript). These are sufficient materials to recognize a pattern of the dispute resolution which in all aspects consistently relied on common standards set in Trento and not on discretion or customary law perceptions of individual arbitration proceedings and the arbitrators involved.

Regardless of its final result (which failed to be achieved), arbitration in the boundary dispute of 1535 testifies that already at the beginning of the $16^{\text {th }}$ century some states were in search of means of peaceful dispute resolution which would eliminate or at least reduce resorting to acts of violence. The arbitration attempt of 1535 indicates that the great political powers realized that such a search had to rely on certain standards, consistency and the law. Far more than its final result, such perceptions of the early $16^{\text {th }}$ century sovereigns are worthy of research and studying because they are surely a part of the foundations of international law as we know it today.

\section{Correspondence:}

Prof. Dr. Ivan MiLOTić

University of Zagreb

Faculty of Law

Trg Republike Hrvatske 14,

HR - 10000 Zagreb

ivan.milotic@pravo.hr

ORCID 0000-0002-6766-8609

\section{Abbreviations:}

ASV Archivio die Stato Venezia

[State Archive Venice]

\section{Bibliography:}

Tatjana BRADARA (ed.), Il confine veneto-austriaco in Istria (Pula 2017).

Marino BuDICIN, Contributo alla conoscenza della vertenza confinaria nelle "differenze" di Zumesco. L'episodio del 1717, in: Atti - Centro di Ricerche Storiche di Rovigno 39 (2009) 223-268.

Helmut COING, Zur Entwicklung des Schiedsvertrages im Jus Commune. Die amicabilis compositio und der Schiedsspruch ex aequo et bono, in: Festschrift für Heinz Hübner zum 70. Geburtstag (Berlin-New York 1974) 35-46.

Fabio CUSIN, Il confine orientale d'Italia nella politica europea del XIV e XV secolo (Trieste 1977).

Guilhelmus DuRANTIS, Speculum iudiciale (manuscript), 1271 [edition: Aalen, 1975]. Also available at: München, Bayerische Staatsbibliothek - 2 Inc.c.a. 282-3/4.

Robert FInLAY, Fabius Maximus in Venice. Doge Andrea Gritti, the War of Cambrai, and the Rise of Habsburg Hegemony, 1509-1530, in: Renaissance Quarterly 53 (2000) 988-1031.

Linda FowLER, Forms of Arbitration, in: Proceedings of the Fourth International Congress of Medieval Canon Law, MIC C/5 (Vaticano 1976) 133-147.

Linda FOWLER-MAGERL, Ordo iudiciorum vel ordo iudiciarius. Begriff und Literaturgattung. Ius Commune Sonderheft 19 (Frankfurt am Main 1984). 
Milena JOKSIMOVIĆ, Jan ŠIPOŠ, La Sentenza Tridentina trascrizione e traduzione, in: Tatjana BRADARA (ed.), Il confine veneto-austriaco in Istria (Pula 2017) 289-334.

Danijela JURIČIĆ ČARGO, Spopadi na avstrijsko-beneški meji v Istri od 1535. do 1615. - obmejno ozemlje gospostva Lupoglav in Rašporskega kapetanata, in: Antonio Miculian (ed.), I confini militari di Venezia e dell'Austria nell'età moderna (Pirano 2005) 45-59.

Christoph KAMPMANN, Arbiter und Friedensstiftung. Die Auseinandersetzung um den politischen Schiedsrichter im Europa der Frühen Neuzeit (Paderborn 2001).

Pietro KANDLER, Notizie storiche di Montona (Trieste 1875).

Daniel-Erasmus KHAN, Territory and Boundaries, in: Bardo Fassbender, Anne Peters, Simone Peter, Daniel HöGgER (eds.), The Oxford Handbook of the History of International Law (Oxford 2012) 225-249.

John E. LAW, The Venetian Mainland State in the Fifteenth Century, in: Transactions of the Royal Historical Society 2 (1992) 153-174.

Randall LeSAFFER, Peace Treaties and the Formation of International Law, in: Bardo FASSBENDER, Anne Peters, Simone Peter, Daniel Högger (eds.), The Oxford Handbook of the History of International Law (Oxford 2012) 71-94.

Tomaso LUCIANI, Capo d'Istria e provincia tutta. Intorno a confini suoi con Trieste e con il contado di Pisino et altre materie raccolte nell'anno 1732, in: Atti e Memorie della Societa Istriana di Archeologia e Storia Patria 7 (1891) 155-202, 355-409 and 8 (1892) 409-478.

Renzo Meregazzi (ed.), Pauli Iovii Opera, vol. 8: Elogia (Rome 1972).

Ivan MiLotić, Aspetti giuridici della linea di demarcazione austro-veneziana in Istria e sua soluzione arbitrale con le Sentenze tridentine, in: Atti - Centro di ricerche storiche di Rovigno 45 (2016) 111145 .
IDEM, Capitolare di Momiano (Buje 2014).

IDEM, La Sentenza Tridentina. Analisi giuridica e interpretazione, in: Tatjana BRADARA (ed.), Il confine veneto-austriaco in Istria (Pula 2017) 335 -361.

Girolamo MONTI, Tractatus definibus regundis civitatum, castrorum, ac praediorum, tam urbanorum, quam rusticorum [...] (Colonia Agrippina [Köln], 1590).

Pio PASChINI, Storia del Friuli (Udine 1975).

Claudio Povolo, Liturgies of Violence. Social Control and Power Relationships in the Republic of Venice between $16^{\text {th }}$ and $18^{\text {th }}$ Centuries, in: Eric $R$. DURSTELER (ed.), A Companion to Venetian History, 1400-1797 (Leiden 2013) 513-542.

Claudio Rossit, Luciano LAGO, Descriptio Histriae, la peninsola Istriana in alcunimomenti significativi della sua tradizione cartografica sino a tutto il secolo XVIII (Trieste 1981).

Saskia SASSEN, Territory, Authority, Rights. From Medieval to Global Assemblages (Princeton 2006).

Merio ScatTOlA, Die Grenze der Neuzeit, in: Markus BAUER, Thomas RAHN (ed.), Die Grenze: Begriff und Inszenierung (Berlin 1997) 37-72.

Heinhard STEIGER, Von der Staatengesellschaft zur Weltrepublik? Aufsätze zur Geschichte des Völkerrechts aus vierzig Jahren (Studien zur Geschichte des Völkerrechts) (Baden-Baden 2008).

Giacomo Filippo TOMmAsinI, De Commentari storici geografici della Provincia dell'Istria, libri otto (1644) (Trieste 2005).

Karl-Heinz ZIEGLER, Arbiter, arbitrator und amicabilis compositor, in: Zeitschrift der Savigny-Stiftung für Rechtsgeschichte, Romanistische Abteilung 94 (1967) 376-381.

IDEM, The influence of medieval Roman law on peace treaties, in: Peace Treaties and International Law in European History From the Late Middle Ages to World War One (Cambridge 2004) 147-161.

Reinhard ZIMMERMANN, Law of Obligations. Roman Foundations of the Civilian Tradition (Oxford 1996). 